\title{
IFAS Community Development: Toward a Consistent Definition of Community Development ${ }^{1}$
}

\author{
Mark A. Brennan ${ }^{2}$ \\ This paper is part of a series of discussions on \\ community development. This series will include \\ specialized papers on civic engagement, community \\ action, and other topics important to the development \\ of community.
}

\section{Introduction}

The need for community development is widely recognized, and the focus of much of our academic, extension, and research efforts. However, there is an inconsistency in the definition, usage, and general understanding of what community development represents. To some it is synonymous with economic development and is characterized by efforts to recruit industry and services. For example, business development, infrastructure improvements, and city planning all often fall under the description of community development. To others community development serves to enhance the social realm that economies and other structures exist in. Included here are efforts to form locally based planning efforts and cross-community resident coalitions to enhance local decision making.
Without a consistent definition of community development, our programs will do little to contribute to the overall improvement and well-being of our communities. And our development efforts are likely to benefit only select segments of our communities. Such development fails to maximize the diverse skills, knowledge, experience, and resources that exist within our communities.

From an interactional perspective, community development is seen as a dynamic process involving diverse social groups (Wilkinson, 1991; Luloff and Swanson, 1995; Luloff and Bridger, 2003). All communities have numerous distinct groupings of people. Through these groups, people act to achieve various interests and goals. Finding common needs and connecting these diverse individual groups is central to community development. Meeting these general needs contributes to the greater well being of the entire locality, while significantly enhancing local structures and/or institutions as well as the environment for small business, entrepreneurial efforts, and other locally based economic development. Furthermore, each of these groups

\footnotetext{
1. This document is FCS 9207, one of a series of the Department of Family, Youth and Community Sciences, Cooperative Extension Service, Institute of Food and Agricultural Sciences, University of Florida. Publication date: December 2004. Reviewed by Hank Cothran, PhD, Institute of Food and Agricultural Sciences, Department of Food and Resource Economics, University of Florida, Gainesville, FL and A.E. Luloff, PhD, Department of Rural Sociology, University of Florida, Gainesville, FL, 32611. Please visit the EDIS website at http://edis.ifas.ufl.edu

2. Mark A. Brennan, PhD, Assistant Professor of Community Development, Department of Family, Youth and Community Sciences, Cooperative Extension Service, Institute of Food and Agricultural Sciences, University of Florida, Gainesville, FL, 32611.
}

The Institute of Food and Agricultural Sciences (IFAS) is an Equal Employment Opportunity - Affirmative Action Employer authorized to provide research, educational information and other services only to individuals and institutions that function without regard to race, creed, color, religion, age, disability, sex, sexual orientation, marital status, national origin, political opinions or affiliations. For information on obtaining other extension publications, contact your county Cooperative Extension Service office. Florida Cooperative Extension Service/Institute of Food and Agricultural Sciences / University of Florida / Larry R. Arrington, Interim Dean 
presents an enormous range of skills, experiences, and methods for addressing local needs and problems. Bringing together these local assets allows for the maximization of local resources and development programs.

\section{The Development of Community}

Community is important in that it contributes to individual and social well being by establishing and maintaining channels of communication, organizing resources to meet local needs, and providing a framework where the collective is more than the sum of its parts (Wilkinson, 1991). Community development can be seen as an action that is purposively directed towards altering local conditions in a positive way (Wilkinson, 1991; Luloff and Bridger, 2003). When specific projects are pursued with an emphasis on building social relationships and communication networks, community development has occurred. Community and community development are based on the assumption that they contribute to the social well being and the self actualization of community members. Community is enhanced when residents work together to address common issues. However, for development to be most effective and to maximize its impact within the locality, it must incorporate both social and economic needs. In understanding this process, the distinction between development of and development in community is important (Summers, 1986; Luloff and Swanson, 1995).

\section{Development in and of Community}

The term community development is sometimes used to represent social or economic change. Many times it is associated with the recruitment or establishment of industry and other economic structures. This constitutes development in community and is often characterized by attempts to enhance specific social components and structures (economies, institutions). This aspect of development is characterized by modernization, outside control of industry, and other characteristics associated with the "growth machine" image of development (Summer, 1986; Bridger and Luloff, 2003). In this context, a community is seen as a given and development is said to enhance this existing entity (Wilkinson, 1991).

From this development in perspective, clearly defined outcomes are envisioned and their achievement signals the success and end of development. An example would include the recruitment of a chain store distribution center by a local community government. In this setting, a process exists in which plans are made to assess both local conditions and the potentially positive impact that a distribution center would have locally. If it is determined that the distribution center is desirable then steps are taken to encourage the location of the industry within the community. Development plans then focus on the successful recruitment of this industry. The corporate decision to locate or not, signals the success or failure of local development efforts. While such indicators or successes are important, focusing only on them ignores the significance of the social realm to the well being of local residents.

The development of specific community areas and systems, while contributing to enhancements of the local community, is not sufficient enough to lead to the emergence of community. Simply enhancing local economies or structures does little to increase the social and cultural connections between residents or to communicate needs and opportunities throughout the locale.

The development of community seeks to enhance the social realm and relationships between people (Summers, 1986). It is the process of interaction, communication, and collective mobilization signaling the development of community that is important. Central to the development of perspective is the establishment of relationships and networks between diverse community members (Wilkinson, 1991; Luloff and Swanson, 1995; Luloff and Bridger, 2003). An example is the establishment of a local community council. Such an effort would begin by bringing together a diverse and representative grouping of the local population in a routine and focused setting. This process allows channels of communication to be established that cut across class and other dividing lines. Through the purposive assessment of skills, needs, and opportunities for 
action, locally based plans for community and economic development that reflect the community can be prepared. The success of individual plans in this setting is irrelevant. Through this development of community, a framework is presented that allows future efforts to be attempted. This model allows for long term community based collective action to take place. Such efforts are purposive and serve as the basis for interaction that benefits the overall community.

\section{Conclusion}

Through community action and the purposive interaction of community members, the development of community takes place (Luloff and Bridger, 2003). This process provides a basis for social and economic development which benefits the entire community by representing all segments of the locale. By building and maintaining channels of communication and interaction, the development of community takes place. Without a local basis for economic and structural change, wide ranging and beneficial efforts cannot be expected (Wilkinson, 1991; Luloff and Swanson, 1995). The development of community and in community can, and should, take place together. One does not preclude the other. Only by developing strong, local social bonds can more effective, focused, and reliable economic development plans be established.

\section{References}

Luloff, A.E., and J. Bridger. 2003. "Community Agency and Local Development.” Pp. 203-213 in, Challenges for Rural America in the Twenty-First Century, edited by D. Brown and L. Swanson. University Park, PA: Pennsylvania State University Press.

Luloff, A. E. and L. Swanson. 1995.

"Community Agency and Disaffection: Enhancing Collective Resources." Pp. 351-372 in Investing in People: The Human Capital Needs of Rural America, edited by L. Beaulieu and D. Mulkey. Boulder, CO: Westview Press.

Summers, G. 1986. "Rural Community Development." Annual Review of Sociology. 12:341-371.
Wilkinson, K. 1991. The Community in Rural America. New York, NY: Greenwood Press.

\section{Suggested Reading}

Community Development Institute East. http://www.ext.wvu.edu/cdi-east/

Southern Rural Development Center. http://srdc.msstate.edu

The Rural Life Center at Kenyon College. http://rurallife.kenyon.edu/

The Community Development Society. http://www.comm-dev.org/

United States Department of Agriculture (USDA) Rural and Community Development. http://www.rurdev.usda.gov/

Council for Urban Economic Development and International Economic Development http://www.iedconline.org/

Civic Practices Network http://www.cpn.org/

The Policy Research Action Group. http://www.luc.edu/depts/curl/prag/

Community Tool Box. http://ctb.lsi.ukans.edu/

Sustainable Development Communication Network. http://www.sdgateway.net

International Association for Community Development. http://www.iacdglobal.org/

Grass-roots.org. http://www.grass-roots.org/

Community Resource Group. http://www.crg.org/ 